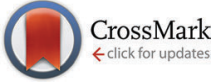

Cite this: Phys. Chem. Chem. Phys., 2016, 18, 3910

Received 13th November 2015, Accepted 5th January 2016

DOI: $10.1039 / \mathrm{c} 5$ cp06963g

www.rsc.org/pccp

\section{A new potassium-based intermediate and its role in the desorption properties of the $\mathrm{K}-\mathrm{Mg}-\mathrm{N}-\mathrm{H}$ system $\dagger$}

\author{
A. Santoru, ${ }^{* a}$ S. Garroni, ${ }^{b}$ C. Pistidda, ${ }^{a}$ C. Milanese, ${ }^{c}$ A. Girella, ${ }^{c}$ A. Marini, ${ }^{c}$ \\ E. Masolo, ${ }^{b}$ A. Valentoni, ${ }^{b}$ N. Bergemann, ${ }^{a}$ T. T. Le, ${ }^{a}$ H. Cao, ${ }^{a}$ D. Haase, ${ }^{d}$ O. Balmes, ${ }^{d}$ \\ K. Taube, ${ }^{a}$ G. Mulas, ${ }^{b}$ S. Enzo, ${ }^{b}$ T. Klassen ${ }^{a}$ and M. Dornheim ${ }^{a}$
}

\begin{abstract}
New insights into the reaction pathways of different potassium/magnesium amide-hydride based systems are discussed. In situ SR-PXD experiments were for the first time performed in order to reveal the evolution of the phases connected with the hydrogen releasing processes. Evidence of a new $\mathrm{K}-\mathrm{N}-\mathrm{H}$ intermediate is shown and discussed with particular focus on structural modification. Based on these results, a new reaction mechanism of amide-hydride anionic exchange is proposed.
\end{abstract}

\section{Introduction}

Among the known hydrogen storage materials, amides represent a promising class of compounds for vehicular on-board applications. ${ }^{1}$ Although the first studies on metal amides date back to the 19th century, ${ }^{2,3}$ only recently the possibility to use them as hydrogen storage materials was reported, i.e. in 2002, when P. Chen et al. described the possibility to use lithium amide combined with lithium hydride for this purpose. ${ }^{4}$

The $\mathrm{LiNH}_{2}-\mathrm{LiH}$ system has a relatively high gravimetric hydrogen capacity ( $6.3 \mathrm{wt} \%$ in the temperature range of $170-$ $\left.210{ }^{\circ} \mathrm{C}\right)$ and interesting thermodynamic properties $\left(\Delta H_{\mathrm{des}} \approx\right.$ $\left.45 \mathrm{~kJ} \mathrm{~mol}{ }^{-1}\right){ }^{4}$ However, during hydrogen desorption, the release of ammonia may also occur. Additionally, in contrast to what it is predicted by the thermodynamic calculations, experimentally temperatures above $275^{\circ} \mathrm{C}$ are necessary to reach 1 bar of equilibrium hydrogen pressure. ${ }^{4}$

The approach of combining different compounds to achieve new hydrogen storage systems with improved thermodynamic properties and high hydrogen storage capacities is a strategy widely adopted, and systems to which this approach applies are

\footnotetext{
${ }^{a}$ Institute of Materials Research, Materials Technology, Helmholtz-Zentrum Geesthacht GmbH, Max-Planck Strasse 1, D-21502 Geesthacht, Schleswig-Holstein, Germany. E-mail: antonio.santoru@hzg.de

${ }^{b}$ Department of Chemistry and Pharmacy, INSTM, Via Vienna 2, I-07100 Sassari, Italy

${ }^{c}$ Pavia H2 Lab, Department of Chemistry, Physical Chemistry Section, University of Pavia, VialeTaramelli 16, I-27100 Pavia, Italy

${ }^{d}$ MAX IV Laboratory, Lund University, Römers väg 1, 22363 Lund, Sweden

$\dagger$ Electronic supplementary information (ESI) available: Additional diffractograms for the characterization of the reaction products and intermediates. DSC trace of $\mathrm{K}_{2} \mathrm{Mg}\left(\mathrm{NH}_{2}\right)_{4}$. See DOI: $10.1039 / \mathrm{c} 5 \mathrm{cp} 06963 \mathrm{~g}$
}

known as Reactive Hydride Composites (RHCs). ${ }^{4-22}$ Recently, $\mathrm{MgH}_{2}$ has been used by Luo ${ }^{23}$ and Xiong et al. ${ }^{24}$ to modify the thermodynamic properties of $\mathrm{LiNH}_{2}$. By this replacement the formation of dilithium magnesium imide (i.e. $\mathrm{Li}_{2} \mathrm{Mg}(\mathrm{NH})_{2}$ ) is possible (reaction (1)):

$$
2 \mathrm{LiNH}_{2}+\mathrm{MgH}_{2} \rightarrow \mathrm{Li}_{2} \mathrm{Mg}(\mathrm{NH})_{2}+2 \mathrm{H}_{2}
$$

The dilithium magnesium imide can also be obtained starting from $\mathrm{Mg}\left(\mathrm{NH}_{2}\right)_{2}$ and $\mathrm{LiH}^{24,25}$ (reaction (2)):

$$
\mathrm{Mg}\left(\mathrm{NH}_{2}\right)_{2}+2 \mathrm{LiH} \leftrightharpoons \mathrm{Li}_{2} \mathrm{Mg}(\mathrm{NH})_{2}+2 \mathrm{H}_{2}
$$

The reaction enthalpy for (2) was estimated by pressurecomposition-temperature measurements to be $38.9 \mathrm{~kJ}$ per mol- $_{2}$. Thus, an equilibrium hydrogen pressure of 1 bar at $90{ }^{\circ} \mathrm{C}$ is expected. ${ }^{26}$ Upon re-hydrogenation, due to the higher thermodynamic stability of $\mathrm{LiH}$ and $\mathrm{Mg}-\mathrm{N}$ bond with respect to the $\mathrm{MgH}_{2}$ and Li-N bond, both systems described in reactions (1) and (2) form magnesium amide and lithium hydride. ${ }^{24}$ Although the very promising thermodynamic properties of this system fall close to the optimal range for mobile applications of $15-25 \mathrm{~kJ}$ per $m o l-\mathrm{H}_{2},{ }^{27,28}$ the release of hydrogen has never been achieved under the thermodynamically calculated temperature and pressure conditions. Indeed an activation energy of $96 \mathrm{~kJ} \mathrm{~mol}^{-1}$ was experimentally determined, which implies the presence of severe kinetic barriers. ${ }^{26}$

To date, the addition of K-based compounds has shown to be beneficial for improving the desorption kinetics of $\mathrm{Mg}\left(\mathrm{NH}_{2}\right)_{2} /$ $2 \mathrm{LiH}^{29-34}$ Upon cycling, all the investigated K-based compounds convert into $\mathrm{KH}^{29,34}$ In this sense, potassium hydride - partially replacing lithium hydride - is regarded as one of the best additives for the $\mathrm{Mg}\left(\mathrm{NH}_{2}\right)_{2} / \mathrm{LiH}$ system, lowering the dehydrogenation temperature by $50-100{ }^{\circ} \mathrm{C} .{ }^{29}$ Recently, the interactions 
between $\mathrm{KH}$ and $\mathrm{Mg}\left(\mathrm{NH}_{2}\right)_{2}$ were also investigated. ${ }^{35}$ According to this study, the desorption path followed by the $\mathrm{Mg}\left(\mathrm{NH}_{2}\right)_{2}-\mathrm{KH}$ system under non-equilibrium conditions is characterized by two main steps with the formation of dipotassium magnesium tetraamide $\left(\mathrm{K}_{2} \mathrm{Mg}\left(\mathrm{NH}_{2}\right)_{4}\right)$ and magnesium imide $(\mathrm{MgNH})$ phases first, and then of the potassium magnesium amide imide phase $\left(\mathrm{KMg}(\mathrm{NH})\left(\mathrm{NH}_{2}\right)\right)$. In a following investigation, the authors hypothesized that $\mathrm{K}_{2} \mathrm{Mg}\left(\mathrm{NH}_{2}\right)_{4}$, forming at the $\mathrm{Mg}\left(\mathrm{NH}_{2}\right)_{2} / \mathrm{KH}$ interface and interacting with $\mathrm{LiH}$, might play a key role in enhancing the hydrogen desorption kinetics of this system. ${ }^{32}$ In the same context, the decomposition of pure $\mathrm{K}_{2} \mathrm{Mg}\left(\mathrm{NH}_{2}\right)_{4}$ and of the $\mathrm{K}_{2} \mathrm{Mg}\left(\mathrm{NH}_{2}\right)_{4} /$ $\mathrm{Mg}\left(\mathrm{NH}_{2}\right)_{2}$ binary mixture was also investigated. ${ }^{35}$ Compared to the earlier crystallographic studies on the thermal decomposition of various $\mathrm{M}_{2} \mathrm{Mg}\left(\mathrm{NH}_{2}\right)_{4}$ phases $^{36,37}$ the results obtained in the recent work by Wang and co-authors ${ }^{35}$ revealed some incongruence. Earlier studies reported the formation of the $\mathrm{K}_{2} \mathrm{Mg}\left(\mathrm{NH}_{2}\right)_{2}(\mathrm{NH})$ and $\mathrm{K}_{2} \mathrm{Mg}(\mathrm{NH})_{2}$ phases in the temperature range of $180-250{ }^{\circ} \mathrm{C}$, and then the formation of $\mathrm{KMgN}$ at about $330{ }^{\circ} \mathrm{C} .{ }^{36,37}$ Instead of the above mentioned phases the recent literature reports the formation of a new phase, namely $\mathrm{KMg}(\mathrm{NH})\left(\mathrm{NH}_{2}\right){ }^{35}$ The crystal structure of this phase was solved only recently by Napolitano et al. ${ }^{38}$ However, the $\mathrm{K}-\mathrm{Mg}-\mathrm{N}-\mathrm{H}$ systems are not yet widely investigated and more efforts are needed in order to understand the kinetic pathways and the underlying hydrogen sorption mechanisms.

In this work the desorption properties, reaction mechanism, and phase evolution of different $\mathrm{K}-\mathrm{Mg}-\mathrm{N}-\mathrm{H}$ systems were studied using a wide range of techniques. In the range of experimental conditions investigated in this work, the possible formation of crystalline $\mathrm{K}_{2} \mathrm{Mg}\left(\mathrm{NH}_{2}\right)_{2}(\mathrm{NH}), \mathrm{K}_{2} \mathrm{Mg}(\mathrm{NH})_{2}$ and $\mathrm{KMgN}$ was disproved by in situ diffraction experiments.

In order to clarify the possible interactions, the $\mathrm{KNH}_{2}-\mathrm{MgH}_{2}$ and $\mathrm{KH}-\mathrm{Mg}\left(\mathrm{NH}_{2}\right)_{2}$ systems were compared. A special emphasis will be put on the structural modifications governing the reaction pathway.

\section{Experimental}

$\mathrm{KH}$ (suspension 35\% in mineral oil) and $\mathrm{MgH}_{2}$ (98\%) were purchased from Sigma-Aldrich. In order to purify $\mathrm{KH}$, the oil was removed washing the powder 3 times with $15 \mathrm{~mL}$ of pentane and then drying it under vacuum. For the synthesis of sample A $0.802 \mathrm{~g}$ and $0.526 \mathrm{~g}$ of $\mathrm{KH}$ and $\mathrm{MgH}_{2}$ (molar ratio $1: 1$ ) were milled under 7 bar of ammonia atmosphere in a High Pressure Vial (Evico-Magnetics) using a ball to powder ratio (BPR) of 10:1 and a total milling time of $20 \mathrm{~h}$. $\mathrm{KNH}_{2}$ and $\mathrm{Mg}\left(\mathrm{NH}_{2}\right)_{2}$ were synthesized separately by repeated mechanochemical treatments of the corresponding metal hydrides under 7 bar of ammonia. After mechanical processing, the $\mathrm{Mg}\left(\mathrm{NH}_{2}\right)_{2}$ sample was also annealed under 7 bar of ammonia for more than $10 \mathrm{~h}$ in a Parr reactor to increase its conversion and crystallinity.

The 1:1 $\mathrm{KNH}_{2}+\mathrm{MgH}_{2}$ and $\mathrm{KH}+\mathrm{Mg}\left(\mathrm{NH}_{2}\right)_{2}$ mixtures were synthesized by grinding the corresponding starting materials in an agate mortar for 10 minutes. Ball milling was not employed to avoid any mechanically induced metathesis reaction or amorphization processes. Thus the materials maintained the original compositional and microstructural state before the in situ SR-PXD experiments were performed.

All the samples were manipulated inside an argon-filled glove box with water and oxygen levels lower than $1 \mathrm{ppm}$.

Thermal desorption mass spectroscopy (TD-MS) was performed using a Netzsch STA 409 for heating up the sample in an alumina crucible at $5{ }^{\circ} \mathrm{C} \mathrm{min}^{-1}$ and under argon flow of $50 \mathrm{~mL}_{n} \mathrm{~min}^{-1}$. The gases released from the sample upon heating were investigated using a HidenAnalytical HAL 201 Mass-Spectrometer.

Sieverts apparatus measurements were performed in a PCTPro2000 instrument, heating the sample with a heating rate of $10{ }^{\circ} \mathrm{C} \mathrm{min}^{-1}$ under a pressure of 1.5 bar of argon. About $150 \mathrm{mg}$ of the sample were loaded into the sample holder. The external holder was then filled with full metal supplements in order to reduce the volume and increase the accuracy of the measurement.

The structural investigation and the phase evolution during the desorption process were performed at the MAX II Synchrotron facility in Lund, Sweden, beamline $1711 .^{39}$ The instrumental geometry of the powder diffractometer is a Debye-Scherrer like configuration with a selected wavelength $\lambda \approx 0.99 \AA$ and a plate image Agilent Titan detector $(2048 \times 2048$ pixel, each of size $60 \times 60 \mu \mathrm{m}^{2}$ ) placed about $80 \mathrm{~mm}$ from the sample holder. The calibration of the instrumental function was carried out using a $\mathrm{LaB}_{6}$ powder. The powdered mixtures were introduced into a borosilicate glass capillary of $1 \mathrm{~mm}$ diameter, sealed to warrant the inert atmosphere in the course of in situ measurement, which was conducted at 1 bar of Ar pressure. The system was heated at $10{ }^{\circ} \mathrm{C} \mathrm{min}^{-1}$ by a thermal element (electric resistance) placed just below the capillary. The temperature was monitored by a thermocouple mounted inside the capillary itself and placed almost in contact with the powder for higher accuracy. ${ }^{40}$ Uncertainties of about $1{ }^{\circ} \mathrm{C}$ were observed if the intermediate values were obtained by interpolation of all the points of the heating ramp or only the 2 values closer to the intermediate one.

The 2-dimensional annular ring patterns were accumulated every 15 or 30 seconds and processed by means of the FIT2D software ${ }^{41}$ which enables to mask on demand critical data due to texture or single crystal spikes and to convert the 2-D data into the "classical" 1-dimensional pattern, intensity-vs.-scattering vector. Piling-up these 1-D patterns, using for example Origin ${ }^{42}$ can supply a contour plot of intensities as a function of the variables: scattering vector $(\mathbf{Q})$, pattern number (scan) and corresponding temperature, respectively.

The ex situ XRD patterns were collected using a Bruker D8 Discover diffractometer with a Cu X-ray lamp $(\lambda=1.54184 \AA)$ and a general area detector in Bragg-Brentano geometry. The diffraction patterns were plotted as a function of the scattering vector $(\mathbf{Q})$ in order to have wavelength independent data, which allows a faster comparison of in situ SR-PXD and ex situ XRD measurements. The reactive samples were protected from oxidation during the measurement employing a PMMA dome sample holder produced by Bruker.

The qualitative and quantitative XRD analyses were performed by MAUD software ${ }^{43,44}$ implementing the Rietveld approach. ${ }^{45,46}$ For the known phases, structural models from the literature were used. ${ }^{38,47-57}$ 
VESTA (Visualization of Electronic and STructural Analysis) was used for graphical representation of the structural models. ${ }^{58}$

\section{Results and discussion}

\section{$\mathrm{KH}-\mathrm{MgH}_{2}-\mathrm{NH}_{3}$ system}

As a first approach we studied the effect of ball milling on the reactivity of the $\mathrm{KH}-\mathrm{MgH}_{2}-\mathrm{NH}_{3}$ system: $\mathrm{KH}+\mathrm{MgH}_{2}$ (1:1 molar ratio) were milled for $20 \mathrm{~h}$ under 7 bar of ammonia at $400 \mathrm{rpm}$ (sample A). The intermediate phases formed during milling were determined by means of ex situ X-ray diffraction. The XRD pattern (Fig. 1) of the as milled sample reveals the formation of $\mathrm{KNH}_{2}, \mathrm{~K}_{2} \mathrm{Mg}\left(\mathrm{NH}_{2}\right)_{4}$ and the presence of un-reacted $\mathrm{MgH}_{2}$. Conversely the other starting reagent, $\mathrm{KH}$, is not detected because it reacted completely with ammonia forming the corresponding amide (reaction (3)). This finding suggests that the reactivity of $\mathrm{MgH}_{2}$ towards $\mathrm{NH}_{3}$ is lower compared to $\mathrm{KH}$ when the reaction is promoted by ball-milling. A recent work on the in situ synthesis of amides revealed that the same difference in reactivity takes place when the reactions are induced by thermal rather than mechanical input. ${ }^{59}$ In light of these events, a multi-step reaction pathway, involving the formation of $\mathrm{Mg}\left(\mathrm{NH}_{2}\right)_{2}$ and $\mathrm{KNH}_{2}$ as intermediate products, can be envisaged as follows:

$$
\begin{gathered}
\mathrm{KH}+\mathrm{NH}_{3} \rightarrow \mathrm{KNH}_{2}+\mathrm{H}_{2} \\
\mathrm{MgH}_{2}+2 \mathrm{NH}_{3} \rightarrow \mathrm{Mg}\left(\mathrm{NH}_{2}\right)_{2}+2 \mathrm{H}_{2} \\
2 \mathrm{KNH}_{2}+\mathrm{Mg}\left(\mathrm{NH}_{2}\right)_{2} \rightarrow \mathrm{K}_{2} \mathrm{Mg}\left(\mathrm{NH}_{2}\right)_{4}
\end{gathered}
$$

The Bragg reflections associated with the $\mathrm{Mg}\left(\mathrm{NH}_{2}\right)_{2}$ phase formation according to reaction (4) were not detected in the room temperature diffraction pattern of sample A (Fig. 1) probably due to its further interaction with $\mathrm{KNH}_{2}$ to form $\mathrm{K}_{2} \mathrm{Mg}\left(\mathrm{NH}_{2}\right)_{4}$ (reaction (5)).

However, the formation of amorphous $\mathrm{Mg}\left(\mathrm{NH}_{2}\right)_{2}$ was already reported in the literature when ball milling is used for the synthesis, therefore the presence of $\mathrm{Mg}\left(\mathrm{NH}_{2}\right)_{2}$ in a nanocrystalline/amorphous state cannot be completely excluded by XRD experiments. ${ }^{47}$

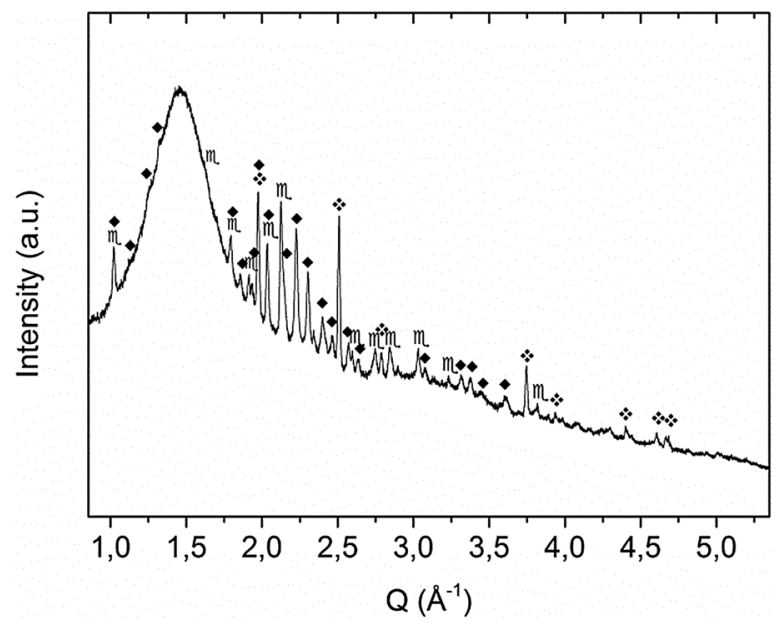

Fig. 1 XRD pattern of sample $A$ as obtained after mechanochemical treatment. $m=\mathrm{KNH}_{2}$ (monoclinic), $\left.=\mathrm{K}_{2} \mathrm{Mg}_{\mathbf{N}} \mathrm{NH}_{2}\right)_{4}=\mathrm{MgH}_{2}$.

\section{Desorption properties}

The desorption properties of sample A were studied by manometric analysis. In order to confirm the reliability of the obtained gravimetric hydrogen capacities, the presence of gaseous ammonia together with hydrogen in the released gases was monitored by thermal desorption mass spectrometry experiments.

According to Fig. 2a, one main desorption step could be observed. In total, about $1.8 \mathrm{wt} \%$ of hydrogen was released after 50 minutes: the process was slow below $200{ }^{\circ} \mathrm{C}\left(<0.2 \mathrm{wt} \%\right.$ of $\mathrm{H}_{2}$ released in the first 20 minutes) but became vigorous above $210{ }^{\circ} \mathrm{C}\left(>1.2 \mathrm{wt} \%\right.$ of $\mathrm{H}_{2}$ released in about 5 minutes).

The corresponding thermal desorption mass-spectrometry experiment presented in Fig. 2b shows a release of mainly $\mathrm{H}_{2}$, the presence of $\mathrm{NH}_{3}$ is almost undetectable.

Ex situ XRD performed on sample A after desorption and re-absorption in the manometric apparatus revealed the formation of $\mathrm{KMgNH}_{2} \mathrm{NH}$ (Fig. 3a), and $\mathrm{KH}$ and $\mathrm{Mg}\left(\mathrm{NH}_{2}\right)_{2}$ (Fig. 3b) phases, respectively.

The measurements indicate that the hydrogenation process proceeded according to reaction (6), in agreement with the data reported by Wang et al., ${ }^{35}$ even if sample preparation and the desorption process were totally different.

$$
\mathrm{KMgNH}_{2} \mathrm{NH}+\mathrm{H}_{2} \rightarrow \mathrm{KH}+\mathrm{Mg}\left(\mathrm{NH}_{2}\right)_{2}
$$

This result suggests that the system obtained upon ball milling is one example of a metastable state, whereas, similar to the
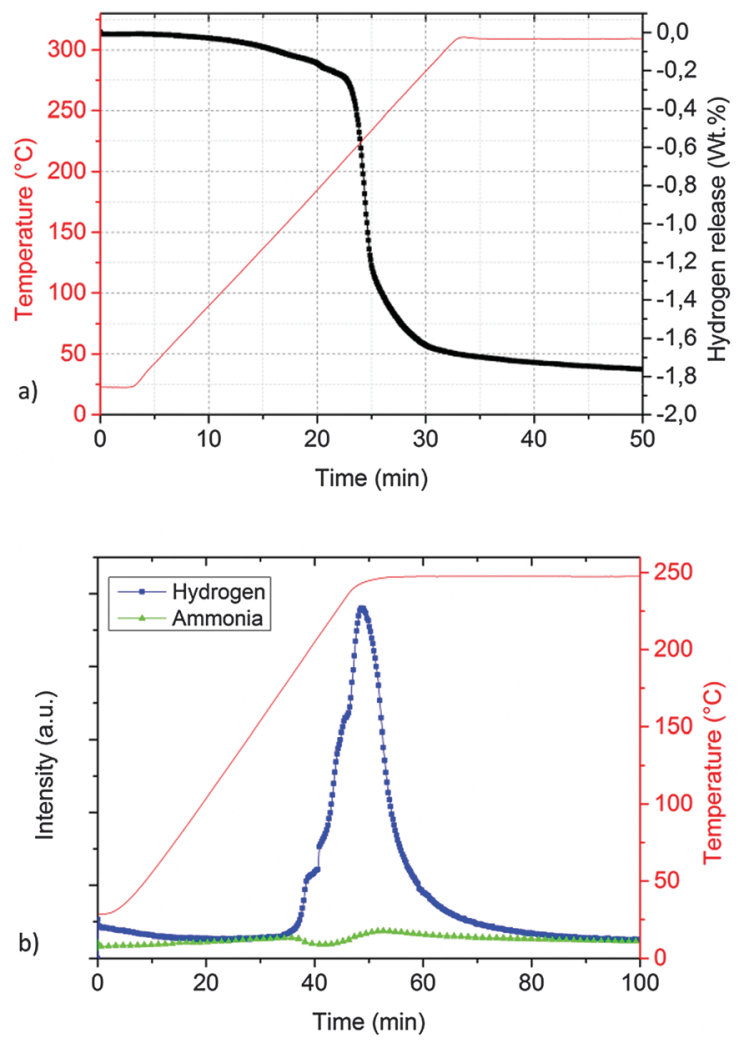

Fig. 2 Desorption properties of sample A determined by a Sieverts apparatus (a) and thermal desorption mass spectrometry (TD-MS) (b). 


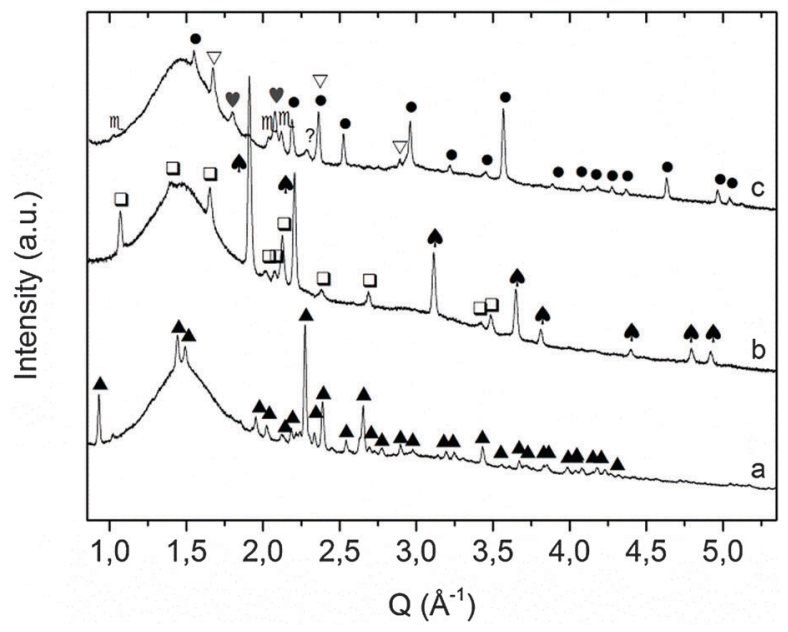

Fig. 3 Room temperature XRD pattern of sample A (a) after desorption at $310^{\circ} \mathrm{C}$ in the Sievert apparatus; (b) after absorption; and (c) after thermal decomposition at $450{ }^{\circ} \mathrm{C}$ under static vacuum. $\mathrm{m}=\mathrm{KNH}_{2}$ (monoclinic), $\boldsymbol{-}=\mathrm{K}_{2} \mathrm{Mg}\left(\mathrm{NH}_{2}\right)_{4},=\mathrm{MgH}_{2}, \boldsymbol{\Delta}=\mathrm{KMgNH}_{2} \mathrm{NH}, \boldsymbol{\square}=\mathrm{Mg}\left(\mathrm{NH}_{2}\right)_{2}, \boldsymbol{\Lambda}=\mathrm{KH}$, $?=$ unknown, $\bullet=\mathrm{Mg}_{3} \mathrm{~N}_{2}, \boldsymbol{\nabla}=\mathrm{K}\left(\mathrm{NH}_{2}\right)_{x} \mathrm{H}_{(1-x)}, \nabla=\mathrm{K}$.

$2 \mathrm{LiNH}_{2}-\mathrm{MgH}_{2} / 2 \mathrm{LiH}-\mathrm{Mg}\left(\mathrm{NH}_{2}\right)_{2}$ systems previously reported, ${ }^{23-25}$ $\mathrm{KH}-\mathrm{Mg}\left(\mathrm{NH}_{2}\right)_{2}$ corresponds to the stable product.

The ex situ XRD performed after thermal treatment of the $\mathrm{KMgNH}_{2} \mathrm{NH}$ product up to $450{ }^{\circ} \mathrm{C}$ under static vacuum, disproved the formation of $\mathrm{KMgN}$ (Fig. 3c) as the decomposition product of the amide-imide phase and revealed the formation of a new cubic phase: the peak position does not match the cubic phase of $\mathrm{KH}$ and the cubic polymorph of $\mathrm{KNH}_{2}$ since a cell parameter of $6.06 \AA$ was found.

This cubic phase is most probably a solid solution of $\mathrm{KNH}_{2}$ and $\mathrm{KH}$ of variable stoichiometry and the different extent of substitution of amide-hydride anions is responsible for the intermediate cell parameter as pointed out in a recent study. ${ }^{59}$ The structural similarities between potassium hydride and the cubic polymorph of $\mathrm{KNH}_{2}$ are several (i.e. the same space group, the same cation, hydride and amide anion have the same charge and the difference between the cell parameters of the two pure phases is below 10\%). Due to the structural relationships the formation of a solid solution is very likely to occur.

\section{Reaction pathway}

In order to investigate the desorption mechanism of sample A and clarify if the phases reported by Palvadeau and Rouxel ${ }^{36,37}$ are formed as intermediate or metastable components, SR-PXD was employed. Time-resolved SR-PXD is well regarded as a powerful technique for observing structural and microstructural modifications, allowing at the same time the identification of reaction intermediates formed during phase transformations or sorption reactions in solid-state chemistry. ${ }^{60}$

Fig. 4 shows the SR-PXD patterns collected at increasing time intervals and in the temperature range from $25{ }^{\circ} \mathrm{C}$ to $420{ }^{\circ} \mathrm{C}$.

The first variation in the diffraction patterns was related to a phase transformation of potassium amide: in the temperature

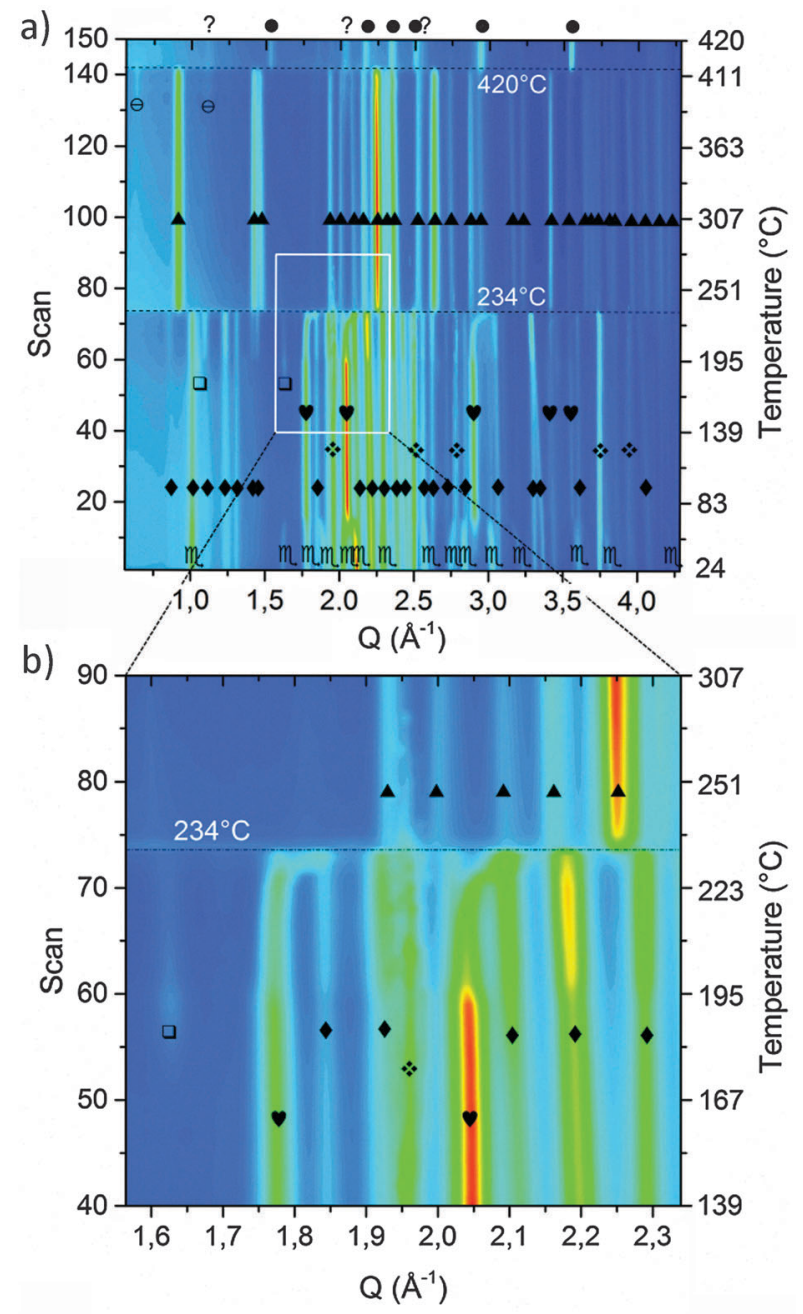

Fig. 4 Contour plot of the SR-PXD experiment conducted on the as-milled sample (a). Zoom in the $Q$-range $1.55-2.35 \AA$ and scans 40-90 (b). $\mathrm{m},=\mathrm{KNH}_{2}$ (monoclinic), $=\mathrm{K}_{2} \mathrm{Mg}\left(\mathrm{NH}_{2}\right)_{4},=\mathrm{MgH}_{2}, \boldsymbol{\nu}=$ $\mathrm{KNH}_{2}(F m \overline{3} \mathrm{~m}), \square=\mathrm{Mg}\left(\mathrm{NH}_{2}\right)_{2}, \boldsymbol{\Delta}=\mathrm{KMgNH}_{2} \mathrm{NH}, \ominus=\mathrm{MgNH}, ?=$ unknown phase, $=\mathrm{Mg}_{3} \mathrm{~N}_{2}$.

range $50{ }^{\circ} \mathrm{C}<T<80{ }^{\circ} \mathrm{C}$ the monoclinic cell rearranged into a cubic geometry through an intermediate tetragonal polymorph of $\mathrm{KNH}_{2}(P 4 / \mathrm{nmm}){ }^{48}$

Increasing the temperature to $167{ }^{\circ} \mathrm{C}$, the Bragg reflections of $\mathrm{Mg}\left(\mathrm{NH}_{2}\right)_{2}$ appeared (Fig. 4a) most probably due to re-crystallization of an amorphous product formed during the synthesis of the sample, as previously hypothesized.

The formation of crystalline $\mathrm{Mg}\left(\mathrm{NH}_{2}\right)_{2}$ could also arise from a metathesis reaction between magnesium hydride and amideion-containing phases $\left(\mathrm{KNH}_{2}\right.$ or $\left.\mathrm{K}_{2} \mathrm{Mg}\left(\mathrm{NH}_{2}\right)_{4}\right)$. However, only the peak intensities of $\mathrm{Mg}\left(\mathrm{NH}_{2}\right)_{2}$ increased in this step: the Bragg reflections of the co-product that would be generated should appear as well, and the intensity of the peaks of the amide-containing phase should decrease as well, but according to the details reported in Fig. 4 this is not the case. Furthermore, the broad signal in the low $Q$-range $\left(Q<1.5 \AA^{-1}\right)$, due to the incoherent scattering from amorphous and/or nanocrystalline phases, disappeared in the same temperature range. 
The subsequent decreased intensity of $\mathrm{Mg}\left(\mathrm{NH}_{2}\right)_{2}$ and $\mathrm{KNH}_{2}$ reflections was associated with an increment of $\mathrm{K}_{2} \mathrm{Mg}\left(\mathrm{NH}_{2}\right)_{4}$ peaks when the temperature reached $195{ }^{\circ} \mathrm{C}$ (see Fig. 4 for details). Most probably the $\mathrm{K}_{2} \mathrm{Mg}\left(\mathrm{NH}_{2}\right)_{4}$ phase is formed by the interaction of $\mathrm{KNH}_{2}$ with $\mathrm{Mg}\left(\mathrm{NH}_{2}\right)_{2}$ according to reaction (5).

Upon increasing the temperature, at $234{ }^{\circ} \mathrm{C}$ a sudden transition in the 2-D diffraction plot is visible (zoom in Fig. 4b). This event coincides with the disappearance of the $\mathrm{K}_{2} \mathrm{Mg}\left(\mathrm{NH}_{2}\right)_{4}$ peaks. The transition is rather fast for being ascribable to a solid state reaction: most likely the observed phenomenon is ascribable to the melting of $\mathrm{K}_{2} \mathrm{Mg}\left(\mathrm{NH}_{2}\right)_{4}$. This supposition is supported by the fact that the background intensity between $5^{\circ}$ and $10^{\circ}$ increases significantly. The DSC measurement on the pure $\mathrm{K}_{2} \mathrm{Mg}\left(\mathrm{NH}_{2}\right)_{4}$ phase also showed an endothermic event in the same temperature range (reported in the $\mathrm{ESI} \dagger-$ Fig S1). Magnesium hydride particles dispersed in the liquid $\mathrm{K}_{2} \mathrm{Mg}\left(\mathrm{NH}_{2}\right)_{4}$ phase reacted releasing hydrogen and forming $\mathrm{KMgNH}_{2} \mathrm{NH}$ according to reaction (7).

$$
\mathrm{K}_{2} \mathrm{Mg}\left(\mathrm{NH}_{2}\right)_{4}+\mathrm{MgH}_{2} \rightarrow 2 \mathrm{KMgNH}_{2} \mathrm{NH}+2 \mathrm{H}_{2}
$$

Indeed the intensity change for the peaks of the two solid phases $\mathrm{MgH}_{2}$ and $\mathrm{KMgNH}_{2} \mathrm{NH}$ is in agreement with the kinetics revealed by manometric measurements and TD-MS (Fig. 2). Surprisingly, neither $\mathrm{K}_{2} \mathrm{Mg}\left(\mathrm{NH}_{2}\right)_{2}(\mathrm{NH})$ nor $\mathrm{K}_{2} \mathrm{Mg}(\mathrm{NH})_{2}$ (predicted by Palvadeau and Rouxel $^{36,37}$ ) could be identified as crystalline components in the patterns in the range of $180-250{ }^{\circ} \mathrm{C}$.

The theoretical capacity of reaction (7) is $2.1 \mathrm{wt} \%$. The difference from the experimental value of $1.8 \mathrm{wt} \%$ determined by a Sievert apparatus could be ascribable to the hydrogen release during milling, as reported in a previous study. ${ }^{35}$

The reproducibility of reaction (7) was cross-checked by another ex situ experiment: $\mathrm{K}_{2} \mathrm{Mg}\left(\mathrm{NH}_{2}\right)_{4}$ and $\mathrm{MgH}_{2}$ (1:1) were ground and then annealed at $280{ }^{\circ} \mathrm{C}$ for $1 \mathrm{~h}$ under $1 \mathrm{bar}$ of argon pressure. The XRD pattern showing the $\mathrm{KMgNH}_{2} \mathrm{NH}$ phase formation is reported in the ESI $\dagger$ (Fig. S2).

Another interesting aspect of the desorption process was revealed by the in situ experiment reported in Fig. 4: below $234{ }^{\circ} \mathrm{C}$, a shift of the cubic $\mathrm{KNH}_{2}$ peaks to higher $Q$-values anticipates the desorption step. Therefore a fast contraction of the cubic $\mathrm{KNH}_{2}$ cell volume takes place. This event is in contrast to the predictable thermal expansion of potassium amide unit cell and may be ascribed to an interaction with magnesium hydride; the mechanism of this interaction will be explored and discussed in the next section.

The amide-imide phase showed high thermal stability (Fig. 4), and the decomposition only took place at $420{ }^{\circ} \mathrm{C}$ in good agreement with the decomposition temperature found by Wang et al. ${ }^{35}$ Due to decomposition, $\mathrm{Mg}_{3} \mathrm{~N}_{2}$ was formed as an end-product while $\mathrm{MgNH}$ is most likely a reaction intermediate for the formation of $\mathrm{Mg}_{3} \mathrm{~N}_{2}$. Also a minor unknown component was produced, differently from the phases previously reported by Palvadeau and Rouxel. ${ }^{36,37}$ Additionally, KMgN was not detected. Complementary in situ and ex situ XRD allowed to prove that the K-containing products at these temperatures were formed in a molten state: indeed they were revealed in the ex situ experiment (Fig. 3c) but undetectable as coherent scattering in the in situ experiment; only an increasing diffuse scattering was noticed, markedly in the low $Q$ region $\left(Q<1.5 \AA^{-1}\right.$, Fig. 4a).

\section{$\mathrm{KNH}_{2}-\mathrm{MgH}_{2}$ system}

The singular behavior evidenced in the potassium amide crystal structure (just below $234{ }^{\circ} \mathrm{C}$ and above $420{ }^{\circ} \mathrm{C}$, Fig. 4 and $3 \mathrm{c}$ respectively) and the scarce information available in the literature motivated further work to explain the previous results. The potassium amide and magnesium hydride mixture was here studied for the first time by in situ SR-PXD to understand the origin of this interaction upon heating and the underlying mechanism. According to the work carried out in recent years by $\mathrm{P}$. Chen et al., the hydrogen release in amidehydride mixtures can arise from the $\mathrm{H}^{\delta+}-\mathrm{H}^{\delta-}$ interaction. ${ }^{26,61}$ The maximum hydrogen capacity is therefore obtained by selecting the system compositions with an equal amount of hydrogen atoms in the oxidation states $(+\mathrm{I})$ and $(-\mathrm{I})$. As a consequence of this strategy for designing systems with higher hydrogen capacities, nitride phases are usually formed upon decomposition and all the hydrogen is released. ${ }^{62}$ Following this approach a study of the $\mathrm{KNH}_{2}-\mathrm{MgH}_{2}$ system could reject or confirm the existence of a $\mathrm{KMgN}$ phase resulting from the interaction between an equal number of hydrogen atoms with partial positive and negative charges.

\section{Reaction pathway and the mechanism}

Due to the preparation of the $\mathrm{KNH}_{2}+\mathrm{MgH}_{2}$ mixture (sample B) in the starting diffraction patterns $\mathrm{KNH}_{2}$ and $\mathrm{MgH}_{2}$ are the major starting components (Fig. 5); an impurity of $\mathrm{Mg}$ was also found to be present in the as-received $\mathrm{MgH}_{2}$.

The temperature of the first desorption step $\left(234{ }^{\circ} \mathrm{C}\right)$ is basically unchanged. Due to the ratio of metal-nitrogen atoms, the desorbed state could not be consistent with the pure $\mathrm{KMgNH}_{2} \mathrm{NH}$ phase as found for sample A. Indeed, according to Fig. 5 b, not only $\mathrm{KMgNH}_{2} \mathrm{NH}$ but also $\mathrm{KH}$ and residual $\mathrm{MgH}_{2}$ were found. For this reason the desorption, expected in this temperature range, can be envisaged as follows:

$$
2 \mathrm{KNH}_{2}+2 \mathrm{MgH}_{2} \rightarrow \mathrm{KMgNH}_{2} \mathrm{NH}+\mathrm{MgH}_{2}+\mathrm{KH}+\mathrm{H}_{2}
$$

Reaction (8) releases $1.2 \mathrm{wt} \%$ of hydrogen, which is in agreement with the value of $1.2 \mathrm{wt} \%$ found by the manometric measurements at the temperature of $240{ }^{\circ} \mathrm{C}$ (Fig. 6a).

However, there was no clear plateau at this point and the desorption continued with the same rate until 1.6-1.7 $\mathrm{wt} \%$ of hydrogen was released.

The additional desorption may depend on the formation of an amorphous imide as an intermediate phase. Ex situ XRD on the sample collected after about $1.7 \mathrm{wt} \%$ of hydrogen was released (Fig. 7a), which revealed the presence of the same phases shown in the in situ measurement at about $250{ }^{\circ} \mathrm{C}$ (Fig. 5b). The cell parameter of $\mathrm{KH}$ was found to be slightly bigger (5.74 vs. $5.70 \AA$ ) which can be explained by the presence of residual amide anions in the structure.

During the measurement the cell parameter of $\mathrm{KNH}_{2}$ undergoes a continuous contraction of the cubic cell. This phenomenon, 

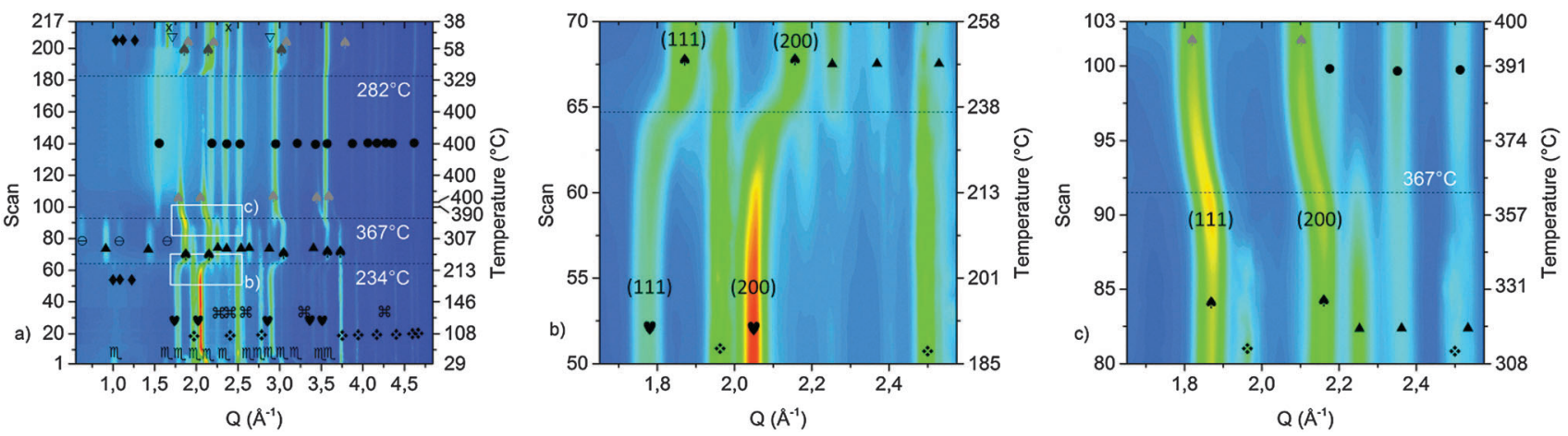

Fig. 5 Contour plot of the SR-PXD experiment conducted on the ground $\mathrm{KNH}_{2}+\mathrm{MgH}_{2}$ (a) and details showing the transformation related to the first and second desorption step (b and c respectively). $\mathrm{m}=\mathrm{KNH}_{2}$ (monoclinic), $=\mathrm{MgH}_{2}$,

$\boldsymbol{V}=\mathrm{KNH}_{2}(\mathrm{Fm} \overline{3} \mathrm{~m}), \mathscr{H}=\mathrm{Mg},=\mathrm{K}_{2} \mathrm{Mg}\left(\mathrm{NH}_{2}\right)_{4}, \boldsymbol{A}=\mathrm{KH}$, $\boldsymbol{\Delta}=\mathrm{KMgNH}_{2} \mathrm{NH}, \ominus=\mathrm{MgNH}, \boldsymbol{\bullet}=\mathrm{Mg}_{3} \mathrm{~N}_{2}, \boldsymbol{Q}=\mathrm{K}\left(\mathrm{NH}_{2}\right)_{x} \mathrm{H}_{(1-x)}, x=\mathrm{K}$-phase, $\nabla=\mathrm{K}$. Grey scale symbols are used to indicate the solid solution in different compositions.
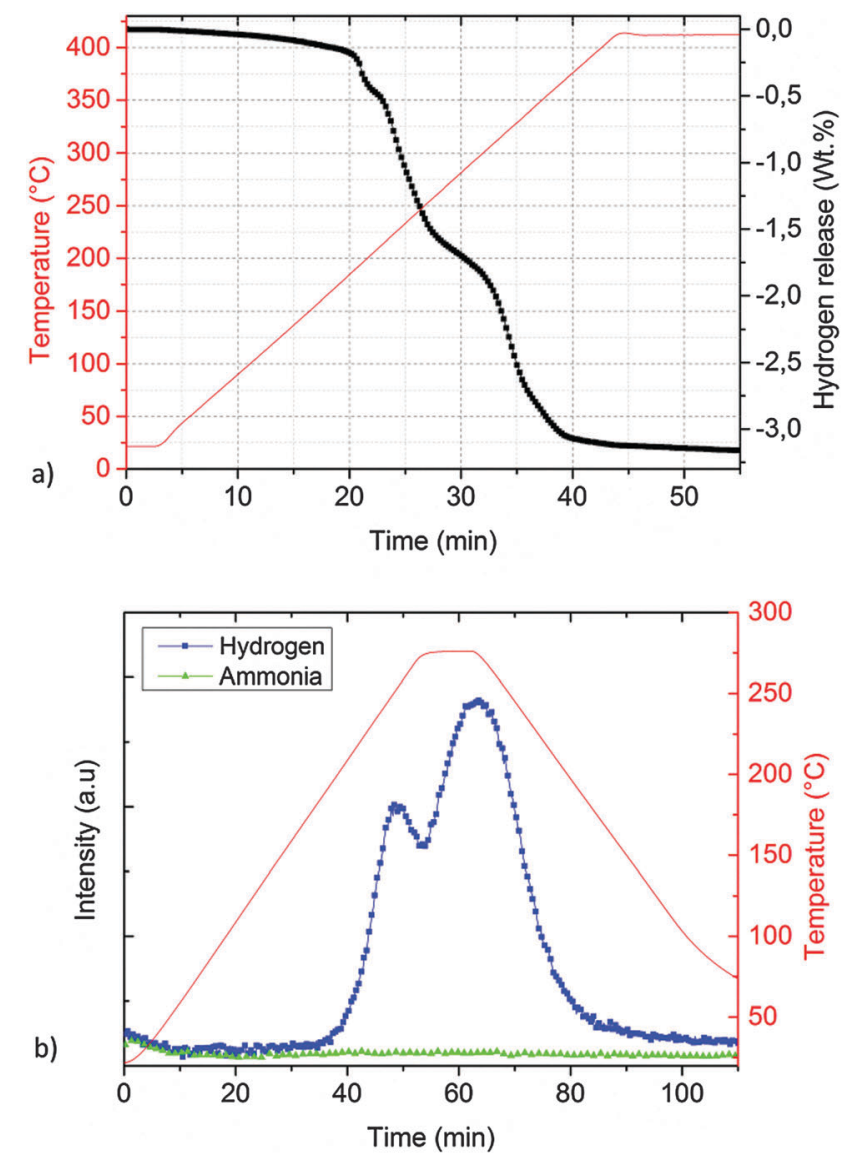

Fig. 6 Desorption properties of ground $\mathrm{KNH}_{2}+\mathrm{MgH}_{2}$ (sample B) determined by: (a) Sieverts apparatus and (b) thermal desorption mass spectrometry.

previously observed for sample $\mathrm{A}$ at rather similar temperature is therefore ascribable to the interaction of $\mathrm{KNH}_{2}$ and $\mathrm{MgH}_{2}$.

According to literature data, the cell parameters at $120{ }^{\circ} \mathrm{C}$ for $\mathrm{KH}$ and cubic $\mathrm{KNH}_{2}$ are $5.73 \AA$ and $6.17 \AA$, respectively. Since the space group and the cation are the same for the two crystal structures, it can be inferred that the different cell length is due to the different ionic radius of the amide and hydride anions

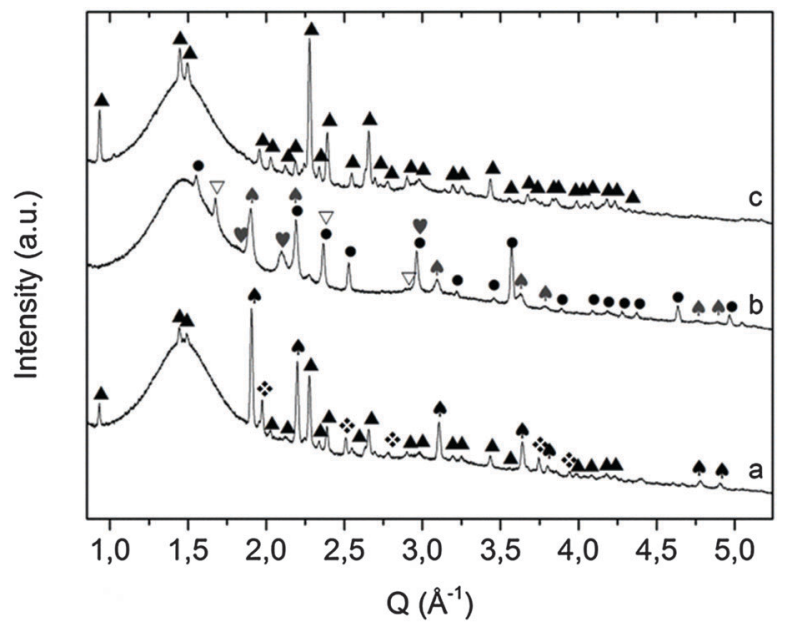

Fig. 7 Room temperature diffractograms of: $\mathrm{KNH}_{2}+\mathrm{MgH}_{2}$ sample collected after desorption in the Sievert apparatus until $255{ }^{\circ} \mathrm{C}$ (a) and $410{ }^{\circ} \mathrm{C}$ (b) respectively; $\mathrm{KH}+\mathrm{Mg}\left(\mathrm{NH}_{2}\right)_{2}$ collected after desorption in a heating ramp RT - $300{ }^{\circ} \mathrm{C}$ in the Sievert apparatus (c). $=\mathrm{MgH}_{2}, \boldsymbol{\Lambda}=\mathrm{KH}, \boldsymbol{\Delta}=\mathrm{KMgNH}_{2} \mathrm{NH}$,

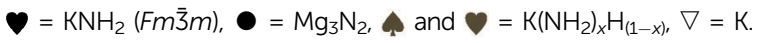

and to the extent of amide-hydride substitution $\left(\mathrm{K}\left(\mathrm{NH}_{2}\right)_{x} \mathrm{H}_{(1-x)}\right.$ where $0 \leq x \leq 1$ ). Therefore the contraction of the cell volume at increasing temperature (Fig. 5b) may be explained by a substitution mechanism of amide groups with smaller anions, namely by hydride anions from $\mathrm{MgH}_{2}$.

David et al. and Makepeace et al. have recently reported a cubic solid solution $\mathrm{Li}_{2-x} \mathrm{NH}_{1+x}$ as an intermediate of the $\mathrm{LiNH}_{2} / \mathrm{Li}_{2} \mathrm{NH}$ structures resulting from the interaction of $\mathrm{LiNH}_{2}$ and $\mathrm{LiH}^{63,64}$ Their in situ XRD experiment clearly showed expansion and contraction of the crystal cell depending on the chemical composition of the $\mathrm{Li}-\mathrm{N}-\mathrm{H}$ intermediates, similar to our case. However, due to different chemistry of the $\mathrm{K}-\mathrm{N}-\mathrm{H}$ system, no stable $\mathrm{K}_{2} \mathrm{NH}$ phases are reported so far. Furthermore the position and relative intensities of the Bragg reflections match the ones of $\mathrm{KNH}_{2}$ and $\mathrm{KH}$ phases as the starting and end-product, respectively (Fig. 5b), and the changing intensity of the $(1,1,1)$ and $(2,0,0)$ Bragg reflections (Fig. $5 \mathrm{~b})$ also supports the structural modification and substitution of amide anions 
by entities with lower scattering strength in the lattice. In summary, by evaluating different chemistry of $\mathrm{LiNH}_{2}-\mathrm{LiH}$ with respect to the $\mathrm{KNH}_{2}-\mathrm{KH}$ case, we propose here for the first time the mechanism of amide-hydride exchange involving the formation of a solid solution even if we should also consider the approach by David et al. and Makepeace et al. ${ }^{63,64}$ where they devised a continuous solid solution of $\mathrm{LiNH}_{2}$ with $\mathrm{Li}_{2} \mathrm{NH}$; of course in our case the existence of the $\mathrm{K}_{2} \mathrm{NH}$ imide compound remains to be demonstrated.

Further increase of temperature up to $234{ }^{\circ} \mathrm{C}$ led to appearance of weak peaks of $\mathrm{K}_{2} \mathrm{Mg}\left(\mathrm{NH}_{2}\right)_{4}$ anticipating the desorption processes (Fig. 5a). Then at $367^{\circ} \mathrm{C}$ all the reflections attributable to $\mathrm{KMgNH}_{2} \mathrm{NH}, \mathrm{MgH}_{2}$ and $\mathrm{MgNH}$ disappeared, magnesium nitride was formed and a fast expansion of the $\mathrm{KH}$ lattice took place (Fig. 5c). According to the data reported in the literature an expansion of the $\mathrm{KH}$ cell volume of about $1 \%$ is expected to take place in the temperature range between 308 and $400{ }^{\circ} \mathrm{C} .{ }^{51}$ Although the thermal expansion of pure $\mathrm{KH}$ is known to follow a linear behavior, ${ }^{51}$ in our experiment (Fig. 5c) for the same temperature range a considerably bigger expansion of the cell volume takes place: the calculated expansion is about $8.5 \mathrm{vol} \%$. Amide anions from $\mathrm{KMgNH}_{2} \mathrm{NH}$ are most probably responsible for this event, while the imide groups further react with hydride anions forming the nitride phase and release hydrogen. The process may be described according to reaction (9).

$$
\begin{aligned}
& 3 \mathrm{KMgNH}_{2} \mathrm{NH}+3 \mathrm{KH}+3 \mathrm{MgH}_{2} \rightarrow 2 \mathrm{Mg}_{3} \mathrm{~N}_{2} \\
& +6 \mathrm{~K}\left(\mathrm{NH}_{2}\right)_{1 / 3} \mathrm{H}_{2 / 3}+5 \mathrm{H}_{2}
\end{aligned}
$$

The total desorption process can be written as reaction (10).

$$
3 \mathrm{KNH}_{2}+3 \mathrm{MgH}_{2} \rightarrow \mathrm{Mg}_{3} \mathrm{~N}_{2}+3 \mathrm{~K}\left(\mathrm{NH}_{2}\right)_{1 / 3} \mathrm{H}_{2 / 3}+4 \mathrm{H}_{2}
$$

During the isothermal interval $\left(T=400{ }^{\circ} \mathrm{C}\right)$ in Fig. 5a the potassium amide-hydride solid solution melts completely and partially decomposes to elemental potassium. During fast cooling down the solidification of two cubic phases with slightly different cell parameter is observed at $282{ }^{\circ} \mathrm{C}$ together with a decrease of the incoherently scattered intensity (Fig. 5, $Q$-range: $1.3-1.8 \AA^{-1}$, patterns 180-200). When the temperature reaches $58{ }^{\circ} \mathrm{C}$ potassium which was present in a molten state crystallizes and also the residual broad signal between $1.5 \AA^{-1}$ and $1.75 \AA^{-1}$ completely disappears (Fig. 5a, patterns 200-217). Other peaks (indicated by $\times$ in Fig. 5b) also appeared at the same moment: the temperature is rather close to the melting point of metallic potassium $\left(63.5{ }^{\circ} \mathrm{C}\right) .{ }^{65} \mathrm{~K}_{2} \mathrm{Mg}\left(\mathrm{NH}_{2}\right)_{4}$ was also detected in traces. The results on the final products were cross-checked with the ex situ XRD acquired on the sample desorbed in the Sievert apparatus (Fig. 7b), showing that the X-phase and $\mathrm{K}_{2} \mathrm{Mg}\left(\mathrm{NH}_{2}\right)_{4}$ were not formed if the cooling down was performed slowly. Therefore the X-phase may be a metastable phase of potassium and its formation, together with $\mathrm{K}_{2} \mathrm{Mg}\left(\mathrm{NH}_{2}\right)_{4}$, was due to the fast cooling down in the ammonia back pressure resulting from the precedent decomposition of $\mathrm{K}\left(\mathrm{NH}_{2}\right)_{x} \mathrm{H}_{(1-x)}$. It is important to underline the safety issues associated with the long term storage of samples containing potassium in their desorbed state, even if the samples are stored in a glove-box under inert atmosphere. ${ }^{66}$
The theoretical value of gravimetric capacity according to reaction (10) (3.3 wt\%) is close to the experimental value of $3.2 \mathrm{wt} \%$ determined by the Sievert apparatus (Fig. 6a).

The hydrogen desorption expected from the in situ PXD and manometric measurement was confirmed by a TD-MS experiment (Fig. 6b). Noteworthily, even if ball milling is known to be beneficial in lowering ammonia release (for example, the magnesium amide-magnesium hydride system ${ }^{67}$ ) for potassium amidemagnesium hydride the ammonia release was rather low compared to the $\mathrm{H}_{2}$ signal, even if the use of ball milling was avoided.

\section{$\mathrm{KH}-\mathrm{Mg}\left(\mathrm{NH}_{2}\right)_{2}$}

The role of KH. According to the work of Wang et al. ${ }^{35}$ when a mixture of $\mathrm{KH}$ and $\mathrm{Mg}\left(\mathrm{NH}_{2}\right)_{2}$ is heated at $2{ }^{\circ} \mathrm{C} \min ^{-1}$ under static vacuum conditions, the components start to interact with each other releasing hydrogen below $100{ }^{\circ} \mathrm{C}$ and reaching a maximum rate of hydrogen release at about $125{ }^{\circ} \mathrm{C}$. However by exchanging the reactants (i.e. $\mathrm{KNH}_{2}+\mathrm{MgH}_{2}$ ) we proved that the interaction is shifted to higher temperatures $\left(c a .210^{\circ} \mathrm{C}\right)$. Using the thermodynamic data reported in the literature ${ }^{68}$ a standard enthalpy change of $-138 \mathrm{~kJ} \mathrm{~mol}^{-1}$ can be calculated for the metathesis reaction (11).

$$
2 \mathrm{KNH}_{2}+\mathrm{MgH}_{2} \rightarrow \mathrm{Mg}\left(\mathrm{NH}_{2}\right)_{2}+2 \mathrm{KH}
$$

The reactants are metastable at room temperature and hydrogen release should occur as an exothermic event: therefore the higher temperature of hydrogen release in our experiment is due to higher kinetic barriers and does not depend on the thermodynamic properties of the system. Moreover even though the metathesis reaction is exothermic and therefore favorable, no metathesis was observed: according to our in situ diffraction experiments if $\mathrm{KH}$ is not present in the system, the desorption takes place at about $230{ }^{\circ} \mathrm{C}$, even when ball milling is employed for the synthesis (sample A). The results suggest that thermodynamic differences arising from different compositions had only a small effect on the desorption temperature during a kinetic experiment and that the formation of the most stable phases $\left(\mathrm{Mg}\left(\mathrm{NH}_{2}\right)_{2}\right.$ and $\left.\mathrm{KH}\right)$ is kinetically hindered during the desorption process: in our experiment (Fig. 5) direct desorption took place.

These considerations motivated the study of the $\mathrm{KH}+\mathrm{Mg}\left(\mathrm{NH}_{2}\right)_{2}$ system, performing an in situ experiment under the same conditions used for studying the $\mathrm{KNH}_{2}+\mathrm{MgH}_{2}$ system, to clarify the reaction mechanism underlying the $\mathrm{Mg}\left(\mathrm{NH}_{2}\right)_{2}-\mathrm{KH}$ interaction (Fig. 8).

According to the study of Wang et al. ${ }^{35}$ when $\mathrm{KH}$ and $\mathrm{Mg}\left(\mathrm{NH}_{2}\right)_{2}$ are heated at $2{ }^{\circ} \mathrm{C} \min ^{-1}$ under static vacuum conditions they react together as follows (reactions (12) and (13))

$$
\begin{aligned}
& 3 \mathrm{Mg}\left(\mathrm{NH}_{2}\right)_{2}+2 \mathrm{KH} \leftrightharpoons \mathrm{K}_{2} \mathrm{Mg}\left(\mathrm{NH}_{2}\right)_{4}+2 \mathrm{MgNH}+2 \mathrm{H}_{2} \\
& \mathrm{~K}_{2} \mathrm{Mg}\left(\mathrm{NH}_{2}\right)_{4}+2 \mathrm{MgNH}+\mathrm{KH} \leftrightharpoons 3 \mathrm{KMgNH}_{2} \mathrm{NH}+\mathrm{H}_{2}
\end{aligned}
$$

However under near-equilibrium conditions (i.e. PCI measurements) direct formation of $\mathrm{KMgNH}_{2} \mathrm{NH}$ is observed according to reaction (14). ${ }^{35}$

$$
\mathrm{Mg}\left(\mathrm{NH}_{2}\right)_{2}+\mathrm{KH} \leftrightharpoons \mathrm{KMgNH}_{2} \mathrm{NH}+\mathrm{H}_{2}
$$




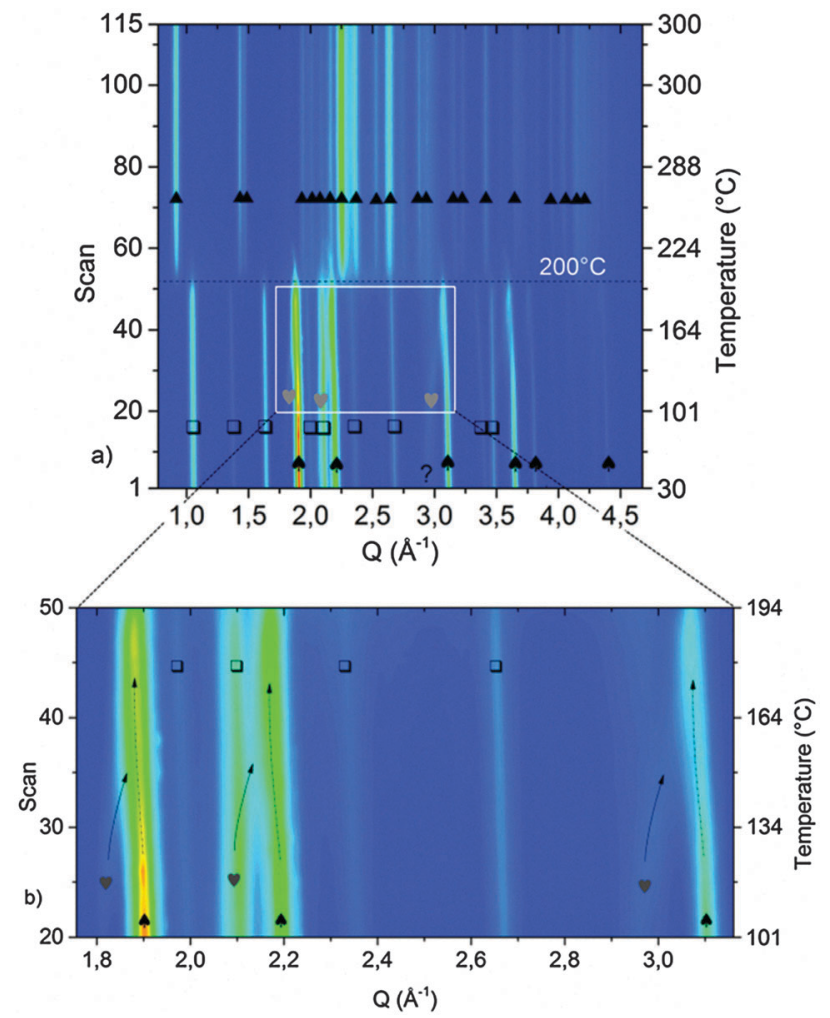

Fig. 8 In situ SR-PXD experiment on the $\mathrm{KH}+\mathrm{Mg}\left(\mathrm{NH}_{2}\right)_{2}$ system (sample C) (a) and details showing the structural modifications taking place above $100{ }^{\circ} \mathrm{C}$ (b). $\boldsymbol{\Lambda}=\mathrm{KH}, \boldsymbol{\square}=\mathrm{Mg}\left(\mathrm{NH}_{2}\right)_{2}, \boldsymbol{\mathrm { K }}\left(\mathrm{NH}_{2}\right)_{x} \mathrm{H}_{(1-x)}, \boldsymbol{\Delta}=\mathrm{KMgNH}_{2} \mathrm{NH}, ?=\mathrm{MgO} / \mathrm{MgNH}$

Due to these results the authors revealed the presence and competition of two different pathways: if enough time was given to the system to reach the thermodynamic equilibrium (at a certain temperature and pressure), the thermodynamic product $\mathrm{KMgNH}_{2} \mathrm{NH}$ was formed - reaction (14); otherwise during kinetics measurement the kinetic products - less stable but accounting for a lower activation energy - are formed (reaction (12)). In our experiment $\mathrm{Mg}\left(\mathrm{NH}_{2}\right)_{2}$ and $\mathrm{KH}$ started to interact at temperatures lower than $100{ }^{\circ} \mathrm{C}$, forming an amide-rich and an amide-poor cubic phase (Fig. 8b).

Indeed the expansion of $\mathrm{KH}$ is linear in the low temperature region as displayed in Fig. 9, but above $100{ }^{\circ} \mathrm{C}$ a fast expansion takes place; at the same time a fast contraction occurs for the $\mathrm{KNH}_{2}$-like structure. Again an exchange mechanism of hydride/ amide anions in the lattice is most probably taking place: the trend of the cell parameters displayed in Fig. 9 clearly shows the lattice of the $\mathrm{KH}$-like structure expanding and that of the $\mathrm{KNH}_{2}$ like structure contracting until they reach similar dimensions.

The amide anions necessary for the formation of the $\mathrm{KNH}_{2}-$ like structure could only come from a reaction between $\mathrm{KH}$ and $\mathrm{Mg}\left(\mathrm{NH}_{2}\right)_{2}$, by direct exchange or $\mathrm{NH}_{3}$-mediated mechanism, as shown in Fig. 10. No other crystalline $\mathrm{Mg}$ co-products were identified, but only an increasing diffuse scattering which supports the formation of an amorphous $\mathrm{Mg}-\mathrm{N}-\mathrm{H}$ product during desorption (Fig. 8, patterns 40-50). Indeed, the formation of an amorphous phase was already observed in structural studies of magnesium amide-magnesium imide phases. ${ }^{47,69}$

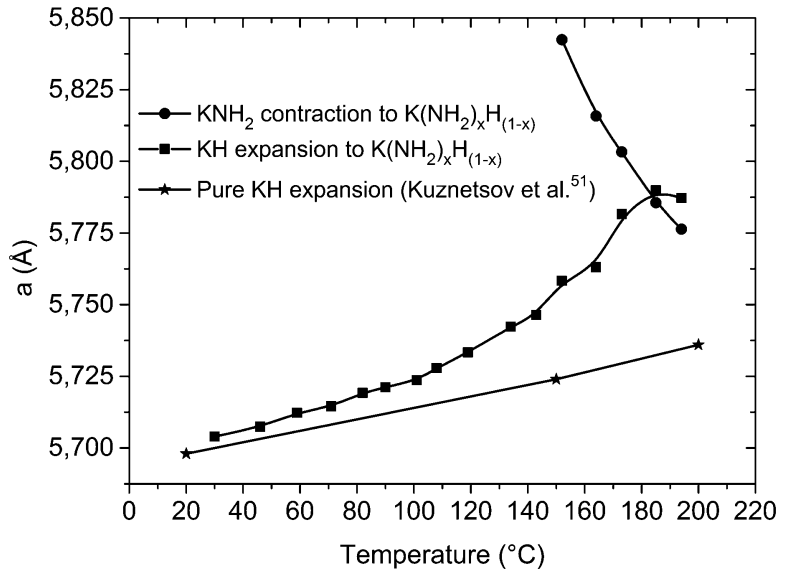

Fig. 9 Variation of the cell parameter "a" for the cubic phases involved in the desorption process, plotted as a function of the temperature. Data from Kuznetsov et al..$^{51}$ were reported for comparison: above $100{ }^{\circ} \mathrm{C}$ the expansion diverged from linearity, and another cubic phase is formed. " $\mathrm{KNH}_{2}$ " and "KH" stay here for a simplification of the amide-rich $(x>0.5)$ and hydride-rich $(x<0.5)$ cubic structures, respectively, with general stoichiometry $\mathrm{K}\left(\mathrm{NH}_{2}\right)_{x} \mathrm{H}_{(1-x)}$.

a)
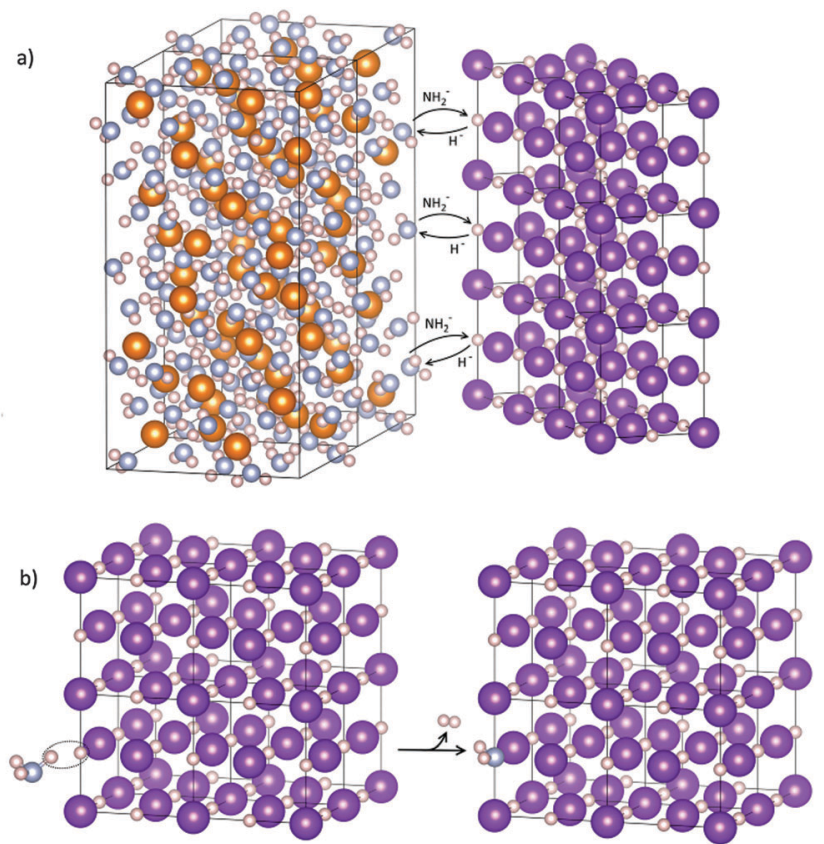

Fig. 10 Possible reaction mechanisms in agreement with the expansion of the cubic cells of $\mathrm{KH}$. Direct exchange of amide-hydride anions at the interface of $\mathrm{KH}$ and $\mathrm{Mg}\left(\mathrm{NH}_{2}\right)_{2}$ (a); $\mathrm{NH}_{3}$-mediated mechanism: ammonia released from $\mathrm{Mg}\left(\mathrm{NH}_{2}\right)_{2}$ reacts with $\mathrm{KH}$ to form $\mathrm{H}_{2}$ molecule and $\mathrm{K}\left(\mathrm{NH}_{2}\right)_{x} \mathrm{H}_{1-x}(\mathrm{~b})$.

Above $200{ }^{\circ} \mathrm{C} \mathrm{Mg}\left(\mathrm{NH}_{2}\right)_{2}$ and the potassium-containing structures react forming $\mathrm{KMgNH}_{2} \mathrm{NH}$ (Fig. 8a).

The absence of molten phases was confirmed by ex situ XRD collected at room temperature, proving $\mathrm{KMgNH}_{2} \mathrm{NH}$ to be the only final product (Fig. 7c). The hydrogen desorption started at temperatures as low as $100{ }^{\circ} \mathrm{C}$ and occurred in a one-step event, with a total capacity of about 2 wt\% (Fig. 11a) and 

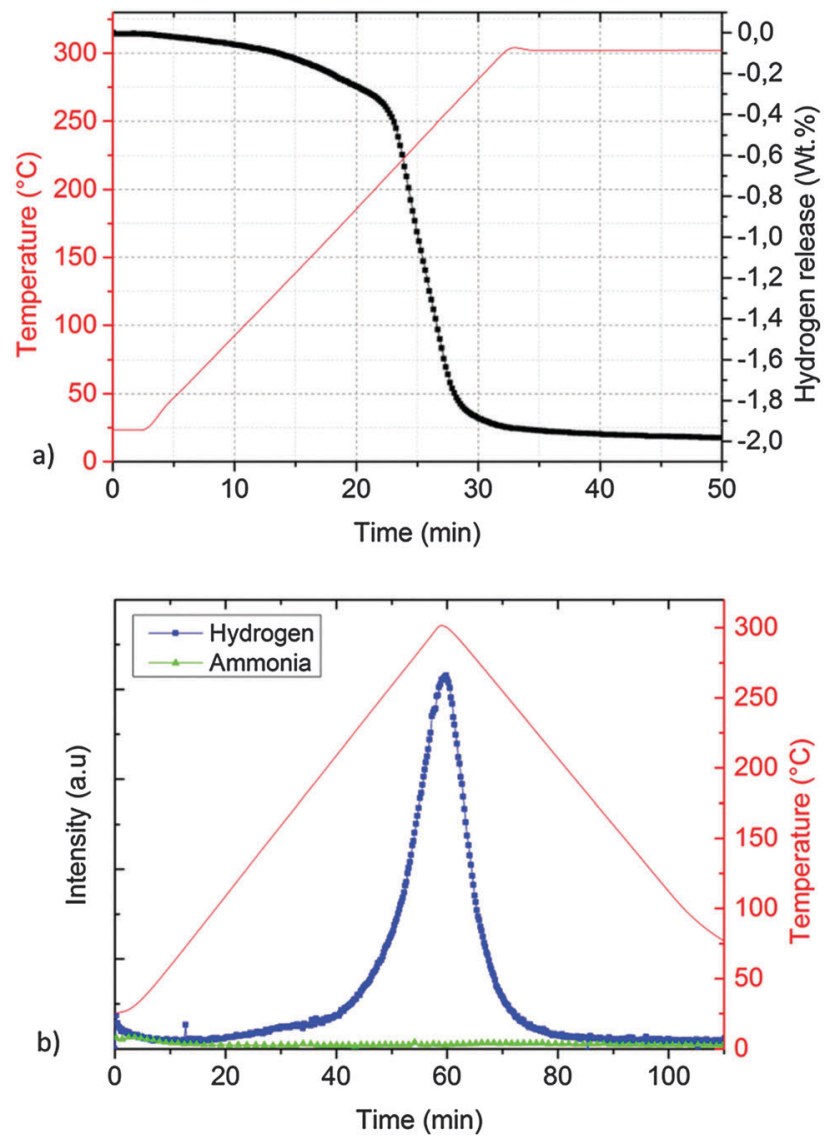

Fig. 11 Manometric measurement (a) and TD-MS measurement (b) performed on the $\mathrm{KH}+\mathrm{Mg}\left(\mathrm{NH}_{2}\right)_{2}$ system (sample $\mathrm{C}$ ).

essentially only hydrogen was released (Fig. 11b) in agreement with literature data. ${ }^{35}$

Our in situ experiments suggest that the formation of $\mathrm{K}\left(\mathrm{NH}_{2}\right)_{x} \mathrm{H}_{(1-x)}$ is a necessary step for hydrogen release for both the $\mathrm{KNH}_{2}+\mathrm{MgH}_{2}$ and $\mathrm{KH}+\mathrm{Mg}\left(\mathrm{NH}_{2}\right)_{2}$ systems. However for the $\mathrm{KH}+\mathrm{Mg}\left(\mathrm{NH}_{2}\right)_{2}$ system desorption started to take place at really low temperatures $\left(<100^{\circ} \mathrm{C}\right)$. Since similar conditions were used for the sample preparation and desorption, this result indicates that $\mathrm{K}\left(\mathrm{NH}_{2}\right)_{x} \mathrm{H}_{(1-x)}$ was more easily formed from the interaction of $\mathrm{KH}$ at the interface with $\mathrm{Mg}\left(\mathrm{NH}_{2}\right)_{2}$ rather than at the $\mathrm{KNH}_{2}-\mathrm{MgH}_{2}$ interface. This may depend on different structural properties of the phases and on the intrinsic activation energy of the two chemical processes. However, for solid state heterogeneous kinetics, part of the activation energy arises from mass transport processes, which are dependent on the particle size, defects in the crystal structures and other parameters which are difficult to tune for a systematic study. The importance of the interface reaction between $\mathrm{Mg}\left(\mathrm{NH}_{2}\right)_{2}$ and $\mathrm{KH}$ in lowering the desorption temperature of the $\mathrm{Mg}\left(\mathrm{NH}_{2}\right)_{2}+1.9 \mathrm{LiH}+0.1 \mathrm{KH}$ mixture was reported in a previous study. ${ }^{32}$ In the current work we propose that by improving the exchange of amide/hydride anions (which is essential for the hydrogen release) the formation of $\mathrm{K}\left(\mathrm{NH}_{2}\right)_{x} \mathrm{H}_{(1-x)}$ phases helps to overcome the kinetic barrier for the interface reaction. These considerations suggest that additives with similar reactivity and structural properties may also be good candidates for the $\mathrm{Mg}\left(\mathrm{NH}_{2}\right)_{2}+2 \mathrm{LiH}$ system. To the best of our knowledge, some amide/borohydride solid solutions were previously found $\mathrm{f}^{70-72}$ but the present work reports the first amide/hydride solid solution.

$\mathrm{K}\left(\mathrm{NH}_{2}\right)_{x} \mathrm{H}_{(1-x)}$ is also the reaction intermediate in the formation of $\mathrm{KNH}_{2}$ by the reaction of ammonia with potassium hydride, when the reaction is promoted either by thermal ${ }^{59}$ or mechanochemical input (ESI $\dagger$ - Fig. S3). Most probably ammonia reacts with the metal hydride at the surface of the particles forming amide anions and hydrogen as already shown in Fig. 10b; then, due to their solubility, amide anions can migrate in the bulk exchanging with hydride anions which further react with ammonia according to reaction (15). This is one of the possible reasons for the higher reactivity with $\mathrm{NH}_{3}$ for $\mathrm{KH}$ compared to $\mathrm{MgH}_{2}$.

$$
\mathrm{KH}+x \mathrm{NH}_{3} \rightarrow \mathrm{K}\left(\mathrm{NH}_{2}\right)_{x} \mathrm{H}_{(1-x)}+x \mathrm{H}_{2}
$$

Moreover, if ammonia is released in a composite system, according to reaction (15), $\mathrm{KH}$ may react catching the nitrogen as an amide anion in the crystal structure and release hydrogen (Fig. 10a), which is in agreement with the really low ammonia desorption found in our experiments, even if ball milling was not used to improve the contacts and dispersion of the biphasic systems $\mathrm{KNH}_{2}+\mathrm{MgH}_{2}$ and $\mathrm{KH}+\mathrm{Mg}\left(\mathrm{NH}_{2}\right)_{2}$. Further studies are being performed to improve the structural description of the new compound.

\section{Conclusions}

The reactivity of a $\mathrm{KH}$ and $\mathrm{MgH}_{2}$ mixture in the amide formation process under ammonia was studied. The reaction pathway of $\mathrm{K}-\mathrm{Mg}-\mathrm{N}-\mathrm{H}$ systems was elucidated and it was rejected the formation of crystalline $\mathrm{K}_{2} \mathrm{Mg}\left(\mathrm{NH}_{2}\right)_{2}(\mathrm{NH}), \mathrm{K}_{2} \mathrm{Mg}(\mathrm{NH})_{2}$ and $\mathrm{KMgN}$ that were hypothesized in the literature as reaction intermediates. $\mathrm{KMgNH}_{2} \mathrm{NH}$ and $\mathrm{Mg}_{3} \mathrm{~N}_{2}$ were shown to be the main product components instead. In situ synchrotron radiation powder X-ray diffraction experiments revealed the structure modifications of potassium hydride-magnesium amide and potassium amide-magnesium hydride systems. For the first time a potassium-amide-hydride solid solution was proved to be a common intermediate of these systems playing a key role in the desorption processes and to be also involved in the synthesis of $\mathrm{KNH}_{2}$. Based on the reported results, a new reaction mechanism for the interaction of $\mathrm{KH}$ with $\mathrm{Mg}\left(\mathrm{NH}_{2}\right)_{2}$ was proposed, involving an exchange of hydride and amide anions between the two phases. The results may help to improve the understanding of the structural modifications promoted by K-based additives at the first stage of the interface reaction with $\mathrm{Mg}\left(\mathrm{NH}_{2}\right)_{2}$.

\section{Acknowledgements}

The research leading to these results has received funding from the European Marie Curie Actions under ECOSTORE grant agreement no. 607040. 


\section{Notes and references}

1 J. H. Wang, H. W. Li and P. Chen, MRS Bull., 2013, 38, 480-487. 2 A. W. Titherley, J. Chem. Soc., Trans., 1894, 65, 504-522.

3 F. W. Dafert and R. Miklauz, Monatsh. Chem., 1910, 31, 981-996.

4 P. Chen, Z. Xiong, J. Luo, J. Lin and K. L. Tan, Nature, 2002, 420, 302-304.

5 U. Bosenberg, S. Doppiu, L. Mosegaard, G. Barkhordarian, N. Eigen, A. Borgschulte, T. R. Jensen, Y. Cerenius, O. Gutfleisch, T. Klassen, M. Dornheim and R. Bormann, Acta Mater., 2007, 55, 3951-3958.

6 E. Deprez, A. Justo, T. C. Rojas, C. Lopez-Cartes, C. B. Minella, U. Bosenberg, M. Dornheim, R. Borrnann and A. Fernandez, Acta Mater., 2010, 58, 5683-5694.

7 J. J. Reilly and R. H. Wiswall, Ber. Bunsen-Ges., 1972, 76, 756. 8 G. Barkhordarian, T. Klassen, M. Dornheim and R. Bormann, J. Alloys Compd., 2007, 440, L18-L21.

9 S. Garroni, C. Milanese, A. Girella, A. Marini, G. Mulas, E. Menendez, C. Pistidda, M. Dornheim, S. Surinach and M. D. Baro, Int. J. Hydrogen Energy, 2010, 35, 5434-5441.

10 S. Garroni, C. B. Minella, D. Pottmaier, C. Pistidda, C. Milanese, A. Marini, S. Enzo, G. Mulas, M. Dornheim, M. Baricco, O. Gutfleisch, S. Surinach and M. D. Baro, Int. J. Hydrogen Energy, 2013, 38, 2363-2369.

11 C. Pistidda, E. Napolitano, D. Pottmaier, M. Dornheim, T. Klassen, M. Baricco and S. Enzo, Int. J. Hydrogen Energy, 2013, 38, 10479-10484.

12 C. Pistidda, D. Pottmaier, F. Karimi, S. Garroni, A. Rzeszutek, M. Tolkiehn, M. Fichtner, W. Lohstroh, M. Baricco, T. Klassen and M. Dornheim, Int. J. Hydrogen Energy, 2014, 39, 5030-5036.

13 D. Pottmaier, C. Pistidda, E. Groppo, S. Bordiga, G. Spoto, M. Dornheim and M. Baricco, Int. J. Hydrogen Energy, 2011, 36, 7891-7896.

14 G. Barkhordarian, T. R. Jensen, S. Doppiu, U. Bosenberg, A. Borgschulte, R. Gremaud, Y. Cerenius, M. Dornheim, T. Klassen and R. Bormann, J. Phys. Chem. C, 2008, 112, 2743-2749.

15 S. Garroni, C. Milanese, D. Pottmaier, G. Mulas, P. Nolis, A. Girella, R. Caputo, D. Olid, F. Teixdor, M. Baricco, A. Marini, S. Surinach and M. D. Baro, J. Phys. Chem. C, 2011, 115, 16664-16671.

16 C. B. Minella, S. Garroni, D. Olid, F. Teixidor, C. Pistidda, I. Lindemann, O. Gutfleisch, M. D. Baro, R. Bormann, T. Klassen and M. Dornheim, J. Phys. Chem. C, 2011, 115, 18010-18014.

17 C. Pistidda, S. Garroni, C. B. Minella, F. Dolci, T. R. Jensen, P. Nolis, U. Bosenberg, Y. Cerenius, W. Lohstroh, M. Fichtner, M. D. Baro, R. Bormann and M. Dornheim, J. Phys. Chem. C, 2010, 114, 21816-21823.

18 C. Pistidda, F. Karimi, S. Garroni, A. Rzeszutek, C. B. Minella, C. Milanese, T. T. Le, L. H. Rude, J. Skibsted, T. R. Jensen, C. Horstmann, C. Gundlach, M. Tolkiehn, P. K. Pranzas, A. Schreyer, T. Klassen and M. Dornheim, J. Phys. Chem. C, 2014, 118, 28409-28417.
19 C. C. Nwakwuo, C. Pistidda, M. Dornheim, J. L. Hutchison and J. M. Sykes, Scr. Mater., 2011, 64, 351-354.

20 C. Pistidda, G. Barkhordarian, A. Rzeszutek, S. Garroni, C. B. Minella, M. D. Baro, P. Nolis, R. Bormann, T. Klassen and M. Dornheim, Scr. Mater., 2011, 64, 1035-1038.

21 J. J. Vajo and G. L. Olson, Scr. Mater., 2007, 56, 829-834.

22 F. Karimi, P. K. Pranzas, A. Hoell, U. Vainio, E. Welter, V. S. Raghuwanshi, C. Pistidda, M. Dornheim, T. Klassen and A. Schreyer, J. Appl. Crystallogr., 2014, 47, 67-75.

23 W. F. Luo, J. Alloys Compd., 2004, 381, 284-287.

24 Z. T. Xiong, G. T. Wu, H. J. Hu and P. Chen, Adv. Mater., 2004, 16, 1522-1525.

25 W. Luo and E. Ronnebro, J. Alloys Compd., 2005, 404, 392-395.

26 Z. T. Xiong, J. J. Hu, G. T. Wu, P. Chen, W. F. Luo, K. Gross and J. Wang, J. Alloys Compd., 2005, 398, 235-239.

27 W. I. F. David, Faraday Discuss., 2011, 151, 399-414.

28 M. Sale, C. Pistidda, A. Taras, E. Napolitano, C. Milanese, F. Karimi, M. Dornheim, S. Garroni, S. Enzo and G. Mulas, J. Alloys Compd., 2013, 580, S278-S281.

29 J. Wang, T. Liu, G. Wu, W. Li, Y. Liu, C. M. Araujo, R. H. Scheicher, A. Blomqvist, R. Ahuja, Z. Xiong, P. Yang, M. Gao, H. Pan and P. Chen, Angew. Chem., 2009, 48, 5828-5832.

30 T. Durojaiye, J. Hayes and A. Goudy, Int. J. Hydrogen Energy, 2015, 40, 2266-2273.

31 W. Luo, V. Stavila and L. E. Klebanoff, Int. J. Hydrogen Energy, 2012, 37, 6646-6652.

32 J. Wang, P. Chen, H. Pan, Z. Xiong, M. Gao, G. Wu, C. Liang, C. Li, B. Li and J. Wang, ChemSusChem, 2013, 6, 2181-2189.

33 C. Liang, Y. Liu, M. Gao and H. Pan, J. Mater. Chem. A, 2013, 1, 5031-5036.

34 Y. Liu, C. Li, B. Li, M. Gao and H. Pan, J. Phys. Chem. C, 2013, 117, 866-875.

35 J. H. Wang, G. T. Wu, Y. S. Chua, J. P. Guo, Z. T. Xiong, Y. Zhang, M. X. Gao, H. G. Pan and P. Chen, ChemSusChem, 2011, 4, 1622-1628.

36 P. Palvadeau and J. Rouxel, C. R. Seances Acad. Sci., Ser. C, 1968, 266, 1605-1607.

37 P. Palvadeau and J. Rouxel, Bull. Soc. Chim. Fr., 1970, 2, 480-485.

38 E. Napolitano, F. Dolci, R. Campesi, C. Pistidda, M. Hoelzel, P. Moretto and S. Enzo, Int. J. Hydrogen Energy, 2014, 39, 868-876.

39 Y. Cerenius, K. Stahl, L. A. Svensson, T. Ursby, A. Oskarsson, J. Albertsson and A. Liljas, J. Synchrotron Radiat., 2000, 7, 203-208.

40 U. Bösenberg, C. Pistidda, M. Tolkiehn, N. Busch, I. Saldan, K. Suarez-Alcantara, A. Arendarska, T. Klassen and M. Dornheim, Int. J. Hydrogen Energy, 2014, 39, 9899-9903.

41 A. P. Hammersley, S. O. Svensson, M. Hanfland, A. N. Fitch and D. Hausermann, High Pressure Res., 1996, 14, 235-248.

42 E. Seifert, J. Chem. Inf. Model., 2014, 54, 1552.

43 L. Lutterotti, S. Matthies, H. R. Wenk, A. S. Schultz and J. W. Richardson, J. Appl. Phys., 1997, 81, 594-600.

44 H. R. Wenk, L. Lutterotti and S. C. Vogel, Powder Diffr., 2010, 25, 283-296. 
45 H. M. Rietveld, J. Appl. Crystallogr., 1969, 2, 65-71.

46 H. M. Rietveld, Acta Crystallogr., 1967, 22, 151-152.

47 F. Dolci, E. Napolitano, E. Weidner, S. Enzo, P. Moretto, M. Brunelli, T. Hansen, M. Fichtner and W. Lohstroh, Inorg. Chem., 2011, 50, 1116-1122.

48 H. Jacobs and E. Von Osten, Z. Naturforsch., 1976, 31b, 385-386.

49 R. Juza, H. Jacobs and W. Klose, Z. Anorg. Allg. Chem., 1965, 338, 171-178.

50 R. Juza and H. Liedtke, Z. Anorg. Allg. Chem., 1957, 290, 205-208.

51 V. G. Kuznetsov and M. M. Shkrabkina, J. Struct. Chem., 1962, 3, 532-537.

52 H. Jacobs, Z. Anorg. Allg. Chem., 1971, 382, 97-109.

53 F. H. Ellinger, C. E. Holley, B. B. McInteer, D. Pavone, R. M. Potter, E. Staritzky and W. H. Zachariasen, J. Am. Chem. Soc., 1955, 77, 2647-2648.

54 J. David, Y. Laurent and J. Lang, Bull. Soc. Fr. Mineral. Cristallogr., 1971, 94, 340-346.

55 E. A. Owen, L. Pickup and I. O. Roberts, Z. Kristallogr. Cryst. Mater., 1935, 91, 70-76.

56 H. Jacobs, J. Birkenbeul and J. Kockelkorn, J. Less-Common Met., 1984, 97, 205-214.

57 C. S. Barrett, Acta Crystallogr., 1956, 9, 671-677.

58 K. Momma and F. Izumi, J. Appl. Crystallogr., 2011, 44, 1272-1276.

59 C. Pistidda, A. Santoru, S. Garroni, N. Bergemann, A. Rzeszutek, C. Horstmann, D. Thomas, T. Klassen and M. Dornheim, J. Phys. Chem. C, 2015, 119, 934-943.
60 A. K. Cheetham and A. P. Wilkinson, Angew. Chem., Int. Ed., 1992, 31, 1557-1570.

61 H. Cao, Y. Zhang, J. Wang, Z. Xiong, G. Wu and P. Chen, Progress in Natural Science: Materials International, 2012, 22, 550-560.

62 Y. Nakamori, G. Kitahara and S. Orimo, J. Power Sources, 2004, 138, 309-312.

63 W. I. F. David, M. O. Jones, D. H. Gregory, C. M. Jewell, S. R. Johnson, A. Walton and P. P. Edwards, J. Am. Chem. Soc., 2007, 129, 1594-1601.

64 J. W. Makepeace, M. O. Jones, S. K. Callear, P. P. Edwards and W. I. F. David, Phys. Chem. Chem. Phys., 2014, 16, 4061-4070. 65 CRC Handbook of Chemistry and Physics, 91st edn, 2010.

66 L. M. Arnbjerg and T. R. Jensen, Int. J. Hydrogen Energy, 2012, 37, 345-356.

67 J. J. Hu, Z. T. Xiong, G. T. Wu, P. Chen, K. Murata and K. Sakata, J. Power Sources, 2006, 159, 120-125.

68 G. Aylward and T. Findlay, Thermodynamic database: SI chemical data, 4th edn, 1998.

69 U. Ash-Kurlander, G. E. Shter, S. Kababya, A. Schmidt and G. S. Grader, J. Phys. Chem. C, 2013, 117, 1237-1246.

70 T. Noritake, M. Aoki, S. Towata, A. Ninomiya, Y. Nakamori and S. Orimo, Appl. Phys. A: Mater. Sci. Process., 2006, 83, 277-279.

71 H. Wu, W. Zhou, T. J. Udovic, J. J. Rush and T. Yildirim, Chem. Mater., 2008, 20, 1245-1247.

72 P. A. Chater, W. I. F. David, S. R. Johnson, P. P. Edwards and P. A. Anderson, Chem. Commun., 2006, 2439-2441, DOI: 10.1039/B518243C. 